\title{
Geochronologic, structural and metamorphic constraints on the evolution of the South Tibetan detachment system, Bhutan Himalaya
}

\author{
Dawn A Kellett ${ }^{1 *}$, Djordje Grujic ${ }^{1}$, Isabelle Coutand ${ }^{2}$ and Clare Warren ${ }^{1,3}$ \\ 1 Department of Earth Sciences, Dalhousie University, Halifax, Nova Scotia, B3H 4J1, CANADA \\ 2 Université des Sciences et Technologies de Lille 1, UFR Sciences Terre (SN5), UMR 8157 du C.N.R.S., 59655 Villeneuve d'Ascq Cedex, FRANCE \\ 3 Department of Earth and Environmental Sciences, The Open University, Walton Hall, Milton Keynes MK7 6AA, ENGLAND \\ * For correspondence, email: dawn.kellett@dal.ca
}

Geodynamic models of collisional orogenesis provide predictions about the provenance and pressure-temperature-time-deformation (PTtD) history of material within exposed crustal-scale structures. Focused field studies across relevant natural analogues provide the requisite data against which these models must be tested. Here we present structural, geochronologic, thermochronologic, thermometric and thermo-barometric data from transects across the
South Tibetan detachment system (STDS) in Bhutan (Figure 1) and compare them to model predictions for the equivalent structures in numerical geodynamic models (e.g., Jamieson et al. 2006).

The STDS in Bhutan occurs as two discrete detachments (Hollister and Grujic 2006) similar to the STDS in eastern Nepal (Searle et al. 2003). The upper detachment appears to be a brittle-ductile normal fault, which juxtaposes the poly-deformed

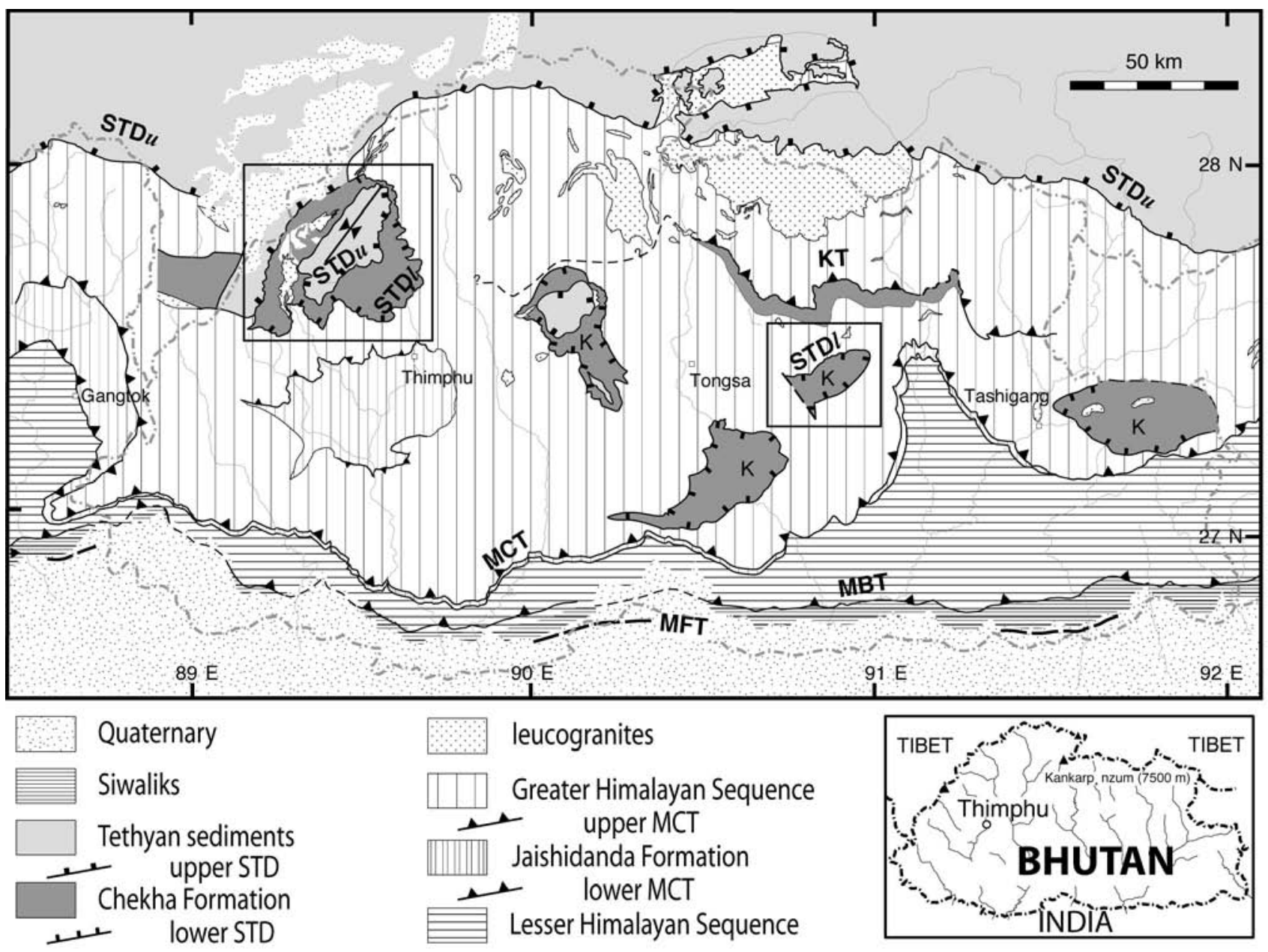

FIGURE 1. Geological map of Bhutan, with field areas enclosed in boxes. K, klippen of Chekha Formation; STDu, upper South Tibetan detachment; STDI, lower South Tibetan detachment; MCT, Main Central thrust; MBT, Main Boundary thrust; MFT, Main Frontal thrust. From Hollister and Grujic 2006 and unpublished data. 
metasedimentary Chekha Group against unmetamorphosed Tethyan sedimentary rocks. The timing of motion along the upper detachment has been constrained to <12-11 $\mathrm{Ma}$ in northern Bhutan by $\mathrm{U}-\mathrm{Pb}$ zircon dating of cross-cutting leucogranites (Edwards and Harrison 1997, Wu et al. 1998).

The lower detachment is a ductile, top-to-the-north shear zone separating high-grade metamorphic rocks of the Greater Himalayan sequence (GHS) in the footwall from the Chekha Group in the hangingwall. It is characterized by pervasive intrusion of multi-generational Tertiary leucogranite dikes and sills. These granite bodies have been variably boudinaged and folded by the detachment. SHRIMP-RG U-Pb dating combined with trace element geochemical analysis of concentrically-zoned magmatic zircon rims indicates pre- to syn-deformational emplacement and crystallization of the leucogranite dikes into Chekha Group rocks during $\sim 23-16 \mathrm{Ma}$, reflecting ductile motion along the lower South Tibetan detachment since at least $16 \mathrm{Ma}$. Porous, inclusion-rich, U-rich zircon cores may indicate early magmatic crystallization of zircon within a highly-fractionated partial melt between 30 and $20 \mathrm{Ma}$.

Ti-in-zircon thermometry of dated zircon rims suggests slow cooling during zircon crystallization from $\sim 650^{\circ} \mathrm{C}$ to $\sim 500^{\circ} \mathrm{C}$ between 23 and $16 \mathrm{Ma}$. Crystallization temperatures are well below the closure temperature for $\mathrm{Pb}$ diffusion in zircon, suggesting that the spread of ages reflects protracted crystallization during the Early Miocene. 40Ar/39Ar step-heat ages from bulk separate igneous muscovite from the leucogranite dikes (same samples) indicate rapid cooling to below $\sim 350^{\circ} \mathrm{C}$, and hence cessation of ductile shearing by $\sim 13-11 \mathrm{Ma}$. Apatite fission track data indicate that the lower detachment reached $110-120^{\circ} \mathrm{C}$ at $5-8$ $\mathrm{Ma}$, thus the cooling rate slowed slightly into the Late Miocene.

The peak temperature gradient across both strands of the STDS in NW Bhutan has been determined by Raman spectroscopy of carbonaceous material and conventional thermobarometry in low- and high-grade metamorphic rocks, respectively. Peak temperatures in the Tethyan sequence increase down-section from $\sim 200^{\circ} \mathrm{C}$ in the core of a map-scale syncline (Figure 1) to $\sim 400^{\circ} \mathrm{C}$ in the hanging wall of the upper STDS. Temperatures in the structurally-highest Chekha Group rocks are $>400^{\circ} \mathrm{C}$, but not substantially higher than Tethyan sedimentary rocks, suggesting throw on the upper STDS is not significant.
Peak temperatures continue to increase down-section across the lower STD to $600-750^{\circ} \mathrm{C}$ in the structurally lowest CG and highest GHS rocks respectively. These are higher temperatures than the Ti-in-zircon rim temperatures suggest, indicating that the leucogranites intruded during cooling and exhumation.

The metamorphic sequence across both strands of the STDS is right-way-up, from granulite-facies rocks in the uppermost Greater Himalaya sequence through amphibolite facies in the Chekha Group and into structurally-highest, unmetamorphosed Tethyan sedimentary rocks, confirming the normal sense of shearing observed through the sequence. The lower detachment was most likely active during the Early to Mid-Miocene, and marks the protolith and rheological boundary between the upper (Chekha Group) and middle (GHS) crust. The upper detachment was most likely active since Late Miocene and has contributed to the tectonic denudation of the rocks beneath, as reflected by the rapid cooling of the lower detachment during Late Miocene. These PTtD data provide crucial constraints on the choice of an appropriate geodynamic model for the evolution of the TibetanHimalayan orogen.

\section{References}

Jamieson RA, C Beaumont, MH Nguyen and D Grujic. 2006. Provenance of the Greater Himalayan Sequence and associated rocks: Predictions of channel flow models. In: Law R, MP Searle and L Godin (eds), Channel flow, ductile extrusion, and exhumation in continental collision zones, Geological Society, London, Special Publications 268: 165-182

Edwards MA and TM Harrison. 1997. When did the roof collapse? Late Miocene north-south extension in the high Himalaya revealed by $\mathrm{Th}-\mathrm{Pb}$ monazite dating of the Khula Kangri Granite. Geology 25(6): 543-546

Hollister LS and D Grujic. 2006. Pulsed channel flow in Bhutan. In: Law R, MP Searle and L Godin (eds), Channel flow, ductile extrusion, and exhumation in continental collision zones, Geological Society, London, Special Publications 268: 415-423

Searle M, RL Simpson, RD Law, RR Parrish and DJ Waters. 2003. The structural geometry, metamorphic and magmatic evolution of the Everest massif, High Himalaya of Nepal-South Tibet. Journal of the Geological Society, London 160: 345-366

Wu C, KD Nelson, G Wortman, SD Samson, YYue, J Li, WSF Kidd and MA Edwards. 1998. Yadong cross structure and South Tibetan Detachment in the east central Himalaya $\left(89^{\circ}-90^{\circ} \mathrm{E}\right)$. Tectonics $17(1)$ : 28-45 